\title{
Phosphorus fractions in an agricultural chronosequence under tillage regimes in the Cerrado area in Goiás, Brazil
}

\author{
Frações de fósforo em uma cronossequência de agricultura sob \\ plantio direto no cerrado goiano
}

\author{
Roni Fernandes Guareschi ${ }^{1 *}$; Marcos Gervasio Pereira ${ }^{2}$; Adriano Perin ${ }^{3}$
}

\begin{abstract}
The increase in the amount and quantity of soil organic matter (SOM), as well as the use of phosphorusbased fertilizers in the superficial soil layer in areas under tillage regimes (TR), may affect phosphorus (P) dynamics in the soil. Therefore, the aims of the present work were as follows: to evaluate the inorganic and organic fractions of $\mathrm{P}$ and its lability levels (labile, moderately labile, and moderately resistant) in a Distroferric Red Latosol under tillage regimes (TR) 3, 15, and 20 years after implementation, and to compare them with those of areas of native Cerrado and pastures. We also focus on analyzing the correlations of the $\mathrm{P}$ fractions in these areas with other soil attributes, such as total carbon and nitrogen levels, light organic matter (LOM), chemical and physical granulometric fractions of the SOM, maximum phosphate adsorption capacity (MPAC), and the remaining phosphorus (Prem). In each of these areas, samples were collected from the 0.0-0.05 and 0.05-0.10 m soil layers. An entirely randomized experimental design was used. After TR implementation, the constant use of phosphorusbased fertilizers as well as the incremental addition of SOM resulted in an increase in the levels of labile, moderate labile, and moderately resistant organic and inorganic $\mathrm{P}$, with a tendency for total $\mathrm{P}$ accumulation to be mostly in the inorganic, moderately labile form. The native Cerrado soil presented high levels of labile and moderately labile inorganic P. Pasture areas presented the lowest levels of labile organic and inorganic $\mathrm{P}$, as well as moderately labile and moderately resistant organic P. By principal component analysis (PCA), it was possible to observe alterations in all soil attributes and P levels of the fractions analyzed.
\end{abstract}

Key words: Organic phosphorus. Inorganic phosphorus. Phosphorus adsorption. Organic matter.

\section{Resumo}

O aumento da quantidade e qualidade da matéria orgânica do solo (MOS), bem como a aplicação de fertilizantes fosfatados na camada superficial do solo em áreas de sistema de plantio direto (SPD) podem alterar a dinâmica do P no solo. Desta forma, os objetivos deste trabalho foram avaliar as frações inorgânicas e orgânicas de P e o grau de labilidade destas (lábil, moderamente lábil e moderadamente resistente) de um Latossolo Vermelho Distroférrico sob sistema de plantio direto (SPD) com 3, 15 e 20 anos de implantação, e compará-las a áreas de cerrado nativo e pastagem; bem como, analisar correlações entre os resultados das frações de P destas áreas com outros atributos, tais como, teor de carbono e nitrogênio total, matéria orgânica leve (MOL), frações químicas e físicas granulométricas da MOS, capacidade máxima de adsorção de fosfato (CMAP) e fósforo remanescente (Prem). Em cada uma das áreas foram coletadas amostras nas profundidades de 0,0-0,05 e 0,05-0,10 m. O delineamento

1 Tecnólogo em Produção de Grãos, Pós-Doutorando em Fitotecnia, Dept ${ }^{\circ}$ de Fitotecnia, Universidade Federal Rural do Rio de Janeiro, UFRRJ, Seropédica, RJ, Brasil. E-mail: guareschiecotarelli@hotmail.com

2 Prof. Dr., Dept ${ }^{\circ}$ de Solos, UFRRJ, Seropédica, RJ, Brasil. E-mail: gervasio@ufrrj.br

3 Prof. Dr., Dept ${ }^{\mathrm{o}}$ de Fitotecnia, Instituto Federal Goiano, Campus Rio Verde, Rio Verde, GO, Brasil. E-mail: perinrj@yahoo.com. br

* Author for correspondence 
utilizado foi inteiramente casualizado. $\mathrm{O}$ uso constante de adubação fosfatada, bem como, o incremento da MOS, aumenta com o passar dos anos de adoção do SPD os teores de P orgânico e inorgânico lábil, moderadamente lábil e moderadamente resistente, tendendo a acumular a maior parte do $\mathrm{P}$ total do solo na forma inorgânica e moderadamente lábil. O solo sob Cerrado nativo apresenta altos valores de $\mathrm{P}$ orgânico lábil e moderadamente lábil. A área de pastagem apresentou menores teores de $\mathrm{P}$ orgânico e inorgânico lábil, $\mathrm{P}$ orgânico moderadamente lábil e moderadamente resistente em relação às demais áreas avaliadas. Através da análise de componentes principais (ACP), pode-se verificar interações entre todos os atributos do solo e os teores de $\mathrm{P}$ das frações analisadas.

Palavras-chave: Fósforo orgânico. Fósforo inorgânico. Adsorção de fósforo. Matéria orgânica.

\section{Introduction}

The morphoclimatic domain known as Cerrado includes an area of approximately 200 million hectares and has the second highest biodiversity on Earth (SANO et al., 2007). However, this biome has lost several habitats because of changes in the soil burn regimes and the conversion of natural habitats into agricultural areas (BUSTAMANTE et al., 2012).

In addition to deforestation, another aggravating factor that results from agriculture and livestock implementation is soil degradation due to the lack of appropriate management. In the State of Goiás (GO), Brazil, the lack of fertilization and liming, as well as the low productivity of pasture areas, has caused 3.5 million hectares per year to undergo degradation (ANDRADE et al., 2013). Additionally, many farmers still use the conventional planting system, which, over time, because of the intensive use and lack of coverage of soil, leads to degradation (GUARESCHI, 2013).

Therefore, the system of tillage regimes (TR), because of basic usage principles such as maintenance of plant residues at the surface, culture rotation, and minimal soil revolvement (only at the sowing line), has emerged as an alternative to minimize soil degradation processes and production costs (SIQUEIRA NETO et al., 2010).

In recent years, the studies in soil organic matter (SOM) dynamics and its effects on soil chemical and physical attributes depending on the time since TR implementation in the Cerrado region have intensified (COSTA JUNIOR, 2008; SILVA et al.,
2008; SIQUEIRA NETO et al., 2010; GUARESCHI et al., 2012, 2013). In these studies, it was observed that depending on the time since TR implementation, the constant delivery of plant residues of different qualities promotes an increase in the total carbon (COSTA JUNIOR, 2008; SIQUEIRA NETO et al., 2010; GUARESCHI et al., 2012; TORMENA et al., 1998) and nitrogen stocks in the superficial soil layers (GUARESCHI et al., 2012, COSTA JUNIOR, 2008).

It was also observed that, depending on the time since TR implementation, there was an increase in the fraction of the more stable humic substances (humic acid and humin) and the organic carbon associated with the silt and clay fractions (GUARESCHI et al., 2013).

The increase in the amount of SOM depending on the time since TR implementation may affect the availability and dynamics of the phosphorus (P) fractions in the soil. According to Guppy et al. (2005), the soluble organic compounds originating from the SOM decomposition can compete for the phosphate adsorption sites in the soil and/or form complexes with metal cations such as iron and aluminum, removing them from the adsorption surface. Additionally, the sorption of SOM compounds may increase the negative charge in the soil surface, hampering phosphate adsorption.

Furthermore, phosphorus-based fertilizers have been frequently used in the soil, accumulating in the superficial layer. Therefore, the fractionation of soil $\mathrm{P}$ may be useful to demonstrate the effect of TR implementation on the liability of this nutrient. 
Through fractionation, phosphate can be separated into the liable, moderately liable, and non-labile forms, assisting in the understanding the dynamics of the availability of this nutrient (SANTOS et al., 2008).

A few studies (PARTELLI et al., 2009; BEUTLER, 2012) have proposed using previous methods for $\mathrm{P}$ inorganic $(\mathrm{Pi})$ and $\mathrm{P}$ organic $(\mathrm{Po})$ extraction (BOWMAN; COLE, 1978; BOWMAN, 1989). With these methods, it is possible to extract the labile, moderately labile, moderately resistant, and resistant $\mathrm{P}$ fractions. Specifically, the different forms of $\mathrm{P}$ are extracted according to $\mathrm{P}$ availability to the plants, with distinct extraction methods (using $\mathrm{NaHCO}_{3}, \mathrm{NaOH}$, or $\mathrm{H}_{2} \mathrm{SO}_{4}$ ). The Po fractions were obtained by the difference between the Pi and the total phosphorus resulting from the use of each extractor (BEUTLER, 2012). According to Gatiboni et al. (2007) and Gonçalves and Meurer (2009), $\mathrm{NaHCO}_{3}$ extracts the labile $\mathrm{Pi}$ and Po fractions, resulting in higher compound availability for plants. The $\mathrm{P}$ fractions extracted using an acid solution $\left(\mathrm{H}_{2} \mathrm{SO}_{4}, 1.79 \mathrm{~mol} \mathrm{~L}^{-1}\right)$ are regarded as moderately labile (BOWMAN; COLE, 1978), whereas an alkali solution $(\mathrm{NaOH})$ has been used to extract the moderately resistant $\mathrm{P}$ fractions (BOWMAN; COLE, 1978).

Studies have been performed on the quantification of $\mathrm{P}$ fractions in TR areas with highly weathered soils in the Cerrado region (SILVA et al., 2003; GALVANI et al., 2008; OLIBONE; ROSOLEM, 2010; CARNEIRO et al., 2011; BEUTLER, 2012). However, the results are contradictory, specifically, when the effect of sources and methods of $\mathrm{P}$ application in TR areas are analyzed, it is possible to observe that $\mathrm{P}$ addition (regardless of sources or methods of $\mathrm{P}$ application) increases the levels of $\mathrm{Po}$ in these areas (GALVANI et al., 2008; OLIBONE; ROSOLEM, 2010). However, studies comparing soils under TR with native Cerrado soils demonstrate that the use of phosphorus-based fertilizers initially decrease the Po and increase the Pi levels (SILVA et al., 2003; CARNEIRO et al., 2011; BEUTLER, 2012).
Therefore, the aims of the present work were to evaluate the inorganic and organic phosphorus fractions and their lability levels (labile, moderately labile, and moderately resistant) in a Distroferric Red Latosol under tillage regimes (TR) of 3, 15, and 20 years after implementation. Additionally, we aimed to compare these fractions to native Cerrado and pasture areas, and analyze the correlations of the $\mathrm{P}$ fractions in these areas with soil attributes, including total carbon and nitrogen levels, light organic matter (LOM), chemical and physical granulometric fractions of the SOM, maximum phosphate adsorption capacity (MPAC), and the remaining levels of phosphorus (Prem).

\section{Materials and Methods}

The study was carried out at the Montividiu Tiuba Farm (17² 27' 52,2” S; 51º 10’33,1” W; 890 m altitude), located in the municipality of Montividiu, GO, Brazil. The average annual precipitation in the region is $1.740 \mathrm{~mm}$, and its climate is tropical. According to Köppen, there are well-defined rainy and dry seasons, and a predominantly plain relief. The soil in this region has been classified as Disferric Red Latosol (EMBRAPA, 2013). The mineral composition of the clay fraction is predominantly caulinite, gibbsite, goethite, and vermiculite, with hidroxy-Al interlayers (GUARESCHI, 2013).

Four cultivation areas were evaluated: 1) the Urochloa decumbens pasture (PA); 2) TR, 3 years after initiating soybean cultivation in summer and allowing fields to lie fallow in the off-season (TR3); 3) TR 15 years after initiating soybean cultivation in summer and corn/sorghum cultivation in the offseason (TR15); and 4) TR 20 years after initiating soybean cultivation in summer and corn in the off-season (TR20). These areas were compared to a native Cerrado stricto sensu (CE) region. All of these areas are located close to one another, within a radius of approximately $5 \mathrm{~km}$, and with the same original soil and soil classification up to the Distroferric RED LATOSOL. In the clay mineral 
fraction there is predominantly caulinite, followed by gibbsita, goethite, and vermiculite with hidroxiAl interlayers (GUARESCHI et al., 2015)

The area of native Cerrado used as a reference is located within the limits of the Montividiu Tiuba Farm in Brazil. The Brachiaria decumbens pasture area has been cultivated for more than 20 years with a density of approximately 1.5 animals per hectare. The TR3, after deforestation of the native Cerrado, was first used as a pasture during 20 years. After this period, it was cultivated with rice for one year, and for the last three years, it has been used for soybean cultivation. The TR15 area has a history of 27 years of conventional cultivation, with soybeans planted in the summer and corn planted in the off-season, the TR was used since 1995 . The TR20 area has the same cultivation history as the TR15, however the RT was implemented in 1990. Both TR15 and TR20 are currently cultivated with soybean in summer and corn or sorghum in the off-season.

The basic fertilization scheme used in the main cultures of the agricultural system was as follows: 1) TR3 and TR 15 had a) soybean (summer): 458 $\mathrm{kg} \mathrm{ha}^{-1}$ with the formulation 02-20-20, respectively of nitrogen, phosphorus and potassium.; b) corn in the off-season: $312 \mathrm{~kg} \mathrm{ha}^{-1}$ of the formulation 12-
$15-15$, in the soil sowing and $120 \mathrm{~kg} \mathrm{ha}^{-1}$ of urea at a coverage of 25 days after emergence (DAE); 2) TR 20 - a) soybean (summer); $200 \mathrm{~kg} \mathrm{ha}^{-1}$ of the formulation $02-20-20+60 \mathrm{~kg} \mathrm{ha}^{-1} \mathrm{~K}_{2} \mathrm{O}$ and $\mathrm{P}_{2} \mathrm{O}_{5}$ in the coverage; b) corn in the off-season: $30 \mathrm{~kg}$ $\mathrm{ha}^{-1} \mathrm{~N}+60 \mathrm{~kg} \mathrm{ha} \mathrm{P}_{2} \mathrm{P}_{5}+70 \mathrm{~kg} \mathrm{ha}^{-1} \mathrm{~K}_{2} \mathrm{O}$ in the groove and $120 \mathrm{~kg} \mathrm{ha}^{-1}$ urea on the coverage at 25 DAE. The TR3 Liming received in 2006 and 2010, while the TR15 already received liming in 2007 and the SPD20 received liming in 2008. Dolomitic limestone $\left(2 \mathrm{mg} \mathrm{ha}^{-1}\right)$ was added to the PA area in 2009.

In September 2010, a representative portion of 2.25 ha $(150 \mathrm{~m} \times 150 \mathrm{~m})$ was delimited to each area, using a spade, 5 deformed samples (each composed of 10 simple samples) were harvested from the 0-0.05 and 0.5-0.10 m layers in a zigzag, with 25\% of the samples harvested from the grooves and $75 \%$ from the sowing area in the TR cultures. The samples were air-dried, broken into smaller pieces, and run through a 2-mm sieve. This resulted in airdried fine soil (ADFS), which was used for chemical characterization and granulometric analysis (EMBRAPA, 1997) (Table 1) and for the analysis of $\mathrm{P}$ fractions in the soil. An entirely randomized design was implemented, with five repetitions for each area.

Table 1. Chemical attributes and granulometric analyses in the areas of Cerrado (CE), pastures (PA), and under tillage regimes (TR) three (TR3), 15 (TR15), and 20 (TR20) after implementation.

\begin{tabular}{|c|c|c|c|c|c|c|c|c|c|c|c|}
\hline \multirow{3}{*}{ Areas } & $\mathrm{pH}$ & $\mathrm{Ca}$ & $\mathrm{Mg}$ & $\mathrm{K}$ & $\mathrm{Al}$ & $\mathrm{H}+\mathrm{Al}$ & $\mathrm{T}$ & \multirow{2}{*}{$\begin{array}{c}\mathrm{V} \\
--\% \text {-- }\end{array}$} & Clay & Silt & Sand \\
\hline & $\mathrm{H}_{2} \mathrm{O}$ & & & & $\mathrm{nol}_{\mathrm{c}} \mathrm{kg}$ & - & & & \multicolumn{3}{|c|}{--------- $\mathrm{g} \mathrm{kg}^{-1}-\mathrm{-}^{-}$} \\
\hline & \multicolumn{11}{|c|}{ 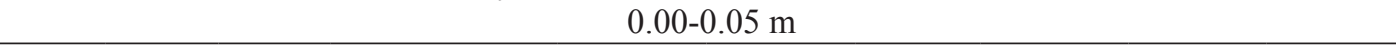 } \\
\hline $\mathrm{CE}$ & 4.4 & 0.8 & 1.9 & 0.2 & 0.5 & 13.3 & 16.2 & 18 & 410 & 170 & 420 \\
\hline PA & 5.7 & 3.9 & 4.7 & 0.2 & 0.0 & 7.3 & 16.3 & 55 & 600 & 190 & 210 \\
\hline TR3 & 5.2 & 1.6 & 2.0 & 0.3 & 0.1 & 3.6 & 7.7 & 53 & 590 & 270 & 140 \\
\hline TR15 & 5.0 & 2.6 & 2.9 & 0.3 & 0.1 & 4.6 & 10.6 & 56 & 630 & 170 & 200 \\
\hline \multirow[t]{2}{*}{ TR20 } & 6.2 & 2.6 & 2.8 & 0.3 & 0.0 & 2.8 & 8.6 & 67 & 410 & 120 & 470 \\
\hline & \multicolumn{11}{|c|}{$0.05-0.10 \mathrm{~m}$} \\
\hline $\mathrm{CE}$ & 3.6 & 0.0 & 1.1 & 0.1 & 0.9 & 9.9 & 11.0 & 11 & 390 & 200 & 410 \\
\hline PA & 5.6 & 3.0 & 3.0 & 0.1 & 0.0 & 5.0 & 11.2 & 55 & 570 & 240 & 190 \\
\hline TR3 & 5.1 & 0.9 & 1.7 & 0.3 & 0.1 & 3.8 & 6.6 & 42 & 610 & 270 & 120 \\
\hline TR15 & 4.9 & 1.9 & 1.9 & 0.3 & 0.2 & 4.0 & 8.2 & 53 & 670 & 160 & 170 \\
\hline TR20 & 5.3 & 1.8 & 1.8 & 0.3 & 0.1 & 3.9 & 7.9 & 50 & 460 & 110 & 430 \\
\hline
\end{tabular}


For the characterization of the total soil, the organic and inorganic $\mathrm{P}$ fractions, we used the method proposed by Bowman (1989). Often the characterization of the labile fraction was separately performed with a sodium bicarbonate $\left(0.5 \mathrm{~mol} \mathrm{~L}^{-1}\right.$ $\mathrm{pH}$ 8.5) extraction, previously used by Bowman and Cole (1978) and modified by Duda (2000). In short, the $\mathrm{P}$ fractionation method used here consisted of a sequential $\mathrm{P}$ extraction using $1 \mathrm{~g}$ samples of ADFS. The first extraction was carried out using a sodium bicarbonate $\left(\mathrm{NaHCO}_{3}\right)$ solution $\left(0.5 \mathrm{~mol} \mathrm{~L}^{-1} \mathrm{pH}\right.$ $8,5)$. The phosphorus fraction, as determined with the use of a spectrophotometer, represented the labile P fraction (EMBRAPA, 1997). The second extraction was performed using concentrated sulfuric acid $\left(\mathrm{H}_{2} \mathrm{SO}_{4}, 1,79 \mathrm{~mol} \mathrm{~L}^{-1}\right)$, using as starting material the soil sample that remained after the first extraction. The second extraction represents the moderately labile $\mathrm{P}$ fraction. The third extraction was performed using a sodium hydroxide $(\mathrm{NaOH})$ solution $\left(0,5 \mathrm{~mol} \mathrm{~L}^{-1}\right)$ on the soil that remained after the second extraction. The $\mathrm{P}$ obtained from the extraction represents the moderately resistant fraction of this nutrient.
The Po levels in the samples were estimated based on the differences between the total $\mathrm{P}$ and the inorganic $\mathrm{P}$ recovered in each extract. The total $\mathrm{P}$ values were found to be a aliquot, subjected to digestion with perchloric acid, and the Pi was identified in the non-digested extracts. Therefore, in order to determinate the organic fraction of each extract, the value for the $\mathrm{P}$ contents in the nondigested extract was subtracted from the value for the $\mathrm{P}$ contents in the digested extract (BOWMAN, 1989).

Data on carbon and nitrogen, light organic matter (LOM), chemical and physical granulometric fraction of the MOS, maximum phosphate adsorption capacity (MPAC), and remaining phosphorus (Prem), which were utilized in this work for principal component analysis (PCA) with the values found for the $\mathrm{P}$ fractions, were obtained from studies carried out by Guareschi et al. (2012, 2013 , 2015) using the same time period, area, and edaphoclimatic conditions as those used in the present study. The average values for these variables are listed in Table 2.

Table 2. Average values of total Carbon (C) and Nitrogen (N), light organic matter (LOM), fulvic acid (FA), humic acid (HA), humin (HU), particle-associated organic carbon (COp), mineral-associated organic carbon (COm), maximum phosphate adsorption capacity (MPAD), and remaining phosphorus (Prem) in the evaluated areas.

\begin{tabular}{|c|c|c|c|c|c|c|c|c|c|c|}
\hline \multirow{3}{*}{ Areas } & $\mathrm{C}$ & $\mathrm{N}$ & LOM & FA & HA & HU & COp & $\mathrm{COm}$ & MPAD & \multirow{2}{*}{$\begin{array}{c}\text { Prem } \\
\mathrm{mg} \mathrm{kg}^{-1}\end{array}$} \\
\hline & \multicolumn{9}{|c|}{-'--} & \\
\hline & \multicolumn{9}{|c|}{$0.00-0.05 \mathrm{~m}$} & \\
\hline${ }^{*} \mathrm{CE}$ & 30.8 & 1.9 & 4.21 & 5.20 & 5.36 & 17.10 & 8.28 & 22.48 & 1.29 & 15.0 \\
\hline PA & 15.4 & 1.0 & 1.23 & 2.84 & 4.72 & 9.75 & 5.40 & 10.05 & 1.50 & 6.9 \\
\hline TR3 & 15.9 & 0.9 & 1.80 & 2.85 & 4.71 & 9.87 & 5.55 & 10.42 & 1.24 & 11.3 \\
\hline TR15 & 29.6 & 1.7 & 1.84 & 3.25 & 4.90 & 16.11 & 4.21 & 25.44 & 1.10 & 13.3 \\
\hline \multirow[t]{2}{*}{ TR20 } & 33.9 & 2.4 & 4.04 & 3.89 & 5.81 & 16.28 & 4.27 & 29.69 & 1.04 & 16.7 \\
\hline & \multicolumn{10}{|c|}{$0.05-0.10 \mathrm{~m}$} \\
\hline $\mathrm{CE}$ & 36.1 & 2.2 & - & 3.80 & 5.63 & 13.57 & 5.20 & 30.86 & 1.34 & - \\
\hline PA & 14.1 & 0.8 & - & 2.94 & 4.50 & 6.02 & 4.23 & 9.85 & 1.37 & - \\
\hline TR3 & 15.4 & 0.9 & - & 2.96 & 4.50 & 6.09 & 4.42 & 11.01 & 1.17 & - \\
\hline TR15 & 27.1 & 1.5 & - & 3.19 & 4.86 & 11.03 & 4.11 & 23.00 & 1.10 & - \\
\hline TR20 & 26.7 & 1.8 & - & 3.76 & 5.77 & 11.26 & 4.19 & 22.53 & 0.98 & - \\
\hline
\end{tabular}

* CE - native cerrado; PA - Pasture; TR3 - tillage system with three years of implementation; TR15 - tillage system with 15 years of implementation; TR20 - tillage system with 20 years of deployment.

Source: Guareschi (2013), Guareschi et al. (2012, 2013, 2015). 
The PCA was performed using the software XLSTAT in combination with Excel. PCA was used to reduce the dimensions of the data, and consequently facilitate the analysis with the generation of a circular correlation diagram.

For all data, from each soil layer, the normality was analyzed with the Lilliefors test, and the homogeneity of the error variances were evaluated with the Cochran and Bartlett's test. The results were subsequently subjected to an analysis of variance using the $\mathrm{F}$ test, and the average values were compared to each other with the Student's $t$-test at the 5\% significance level, using the software ASSISTAT (SILVA; AZEVEDO, 2002).

\section{Results and Discussion}

The PA area presented the lowest levels of total phosphorus (Pt), labile (bic) organic phosphorus (Po), and labile inorganic phosphorus (Pi), when compared to the other areas in both layers evaluated (Table 3). This result can be a consequence of the lack of phosphorus-based fertilization and its inappropriate handling, which also revealed low levels of soil organic matter (SOM), increasing its MPAC (Guareschi et al., 2012, 2015). Similar results were obtained by Beutler (2012), who also found lower Pt-bic and Pi-bic levels in a PA area when compared to an area of TR that combined agriculture-livestock and native Cerrado.

Table 3 shows that there is an increase of Ptbic and Pi-bic contents since TR was first utilized, with the oldest TR area presenting levels of the fractions rather than the $\mathrm{CE}$. The highest Pt-bic and Pi-bic levels in the TR20, when compared to the $\mathrm{CE}$, resulted from successive applications of phosphorus-based fertilizers in the field. According to Bravo et al. (2007), successive applications of phosphorus-based fertilizers promote an increase in phosphorus lability, this is because of the fact that the adsorption sites with a higher affinity for this element are gradually occupied and that new fertilization events increase the amounts of the more labile P fractions. In a similar way, Rodrigues (2013) also observed higher Pi-bic contents in TR areas when compared to native Cerrado with Red Latosol.

Table 3. Levels of total phosphorus (Pt), inorganic phosphorus (Pi), and organic phosphorus (Po), extracted with sodium bicarbonate, from the different soil layers and soil exploration systems, in Montividiu- GO.

\begin{tabular}{|c|c|c|c|c|c|c|}
\hline \multirow{3}{*}{ Depth (m) } & \multicolumn{6}{|c|}{ Systems evaluated ${ }^{1}$} \\
\hline & $\mathrm{CE}$ & PA & TR3 & TR15 & TR20 & $\mathrm{CV}(\%)$ \\
\hline & \multicolumn{6}{|c|}{ Pt-bic $\left(\mathrm{mg} \mathrm{kg}^{-1}\right)$} \\
\hline $0.0-0.05$ & $0.32 \mathrm{~b}^{*}$ & $0.09 \mathrm{~d}$ & $0.17 \mathrm{c}$ & $0.25 \mathrm{~b}$ & $0.49 \mathrm{a}$ & 18.57 \\
\hline \multirow[t]{2}{*}{$0.05-0.10$} & $0.24 \mathrm{c}$ & $0.09 \mathrm{~d}$ & $0.20 \mathrm{c}$ & $0.39 \mathrm{~b}$ & $0.56 \mathrm{a}$ & 13.85 \\
\hline & \multicolumn{6}{|c|}{ Pi-bic $\left(\mathrm{mg} \mathrm{kg}^{-1}\right)$} \\
\hline $0.0-0.05$ & $0.06 \mathrm{c}$ & $0.01 \mathrm{~d}$ & $0.02 \mathrm{~d}$ & $0.12 \mathrm{~b}$ & $0.24 \mathrm{a}$ & 10.53 \\
\hline \multirow[t]{2}{*}{$0.05-0.10$} & $0.08 \mathrm{c}$ & $0.01 \mathrm{~d}$ & $0.02 \mathrm{~d}$ & $0.21 \mathrm{~b}$ & $0.36 \mathrm{a}$ & 22.83 \\
\hline & \multicolumn{6}{|c|}{ Po-bic $\left(\mathrm{mg} \mathrm{kg}^{-1}\right)$} \\
\hline $0.0-0.05$ & $0.26 \mathrm{a}$ & $0.08 \mathrm{c}$ & $0.15 \mathrm{~b}$ & $0.13 \mathrm{~b}$ & $0.25 \mathrm{a}$ & 20.17 \\
\hline $0.05-0.10$ & $0.16 \mathrm{~b}$ & $0.09 \mathrm{c}$ & $0.18 \mathrm{ab}$ & $0.18 \mathrm{ab}$ & $0.20 \mathrm{a}$ & 10.34 \\
\hline
\end{tabular}

*Averages followed by the same lower case letter in a given line indicate solo exploration systems that do not significantly differ according to the t-test at the 5\% significance level. ${ }^{1} \mathrm{CE}$ - native cerrado; PA - Pasture; TR3 - tillage system with three years of implementation; TR15 - tillage system with 15 years of implementation; TR20 - tillage system with 20 years of deployment. 
The increase of the Pt-bic and Pi-bic fractions is a function of time since TR implementation and may be associated with an increase in the SOM levels as well as the reduction of soil MPAC (Guareschi et al., 2015). Several studies have shown that an increase in the levels and/or stocks of carbon in the soil contributes to the increase in the levels of the remaining phosphorus (SOUZA et al. 2006; FONTANA et al., 2008; EBERHARDT et al., 2008; PEREIRA et al., 2010), and/or to the decrease of the MPAC (ALMEIDA et al., 2003; SOUZA et al., 2006, 2010). Specifically, under such conditions the $\mathrm{P}$ availability in weathered soils increases. According to Guppy et al. (2005), the competition between phosphorus and inorganic acids for soil adsorption sites results in an increased $\mathrm{P}$ concentration in the solution. Furthermore, organic compounds such as fulvic and humic acids may form complexes with metal cations such as Fe and $\mathrm{Al}$, decreasing the number of adsorption sites and increasing the availability of these nutrients to the plants (GUPPY et al., 2005). In contrast to the results obtained in the current study, Rotta (2012), when evaluating a chronosequence of TR 7,11 , and 16 years after implementation in a Plinthosol in the State of Goiás, observed that the culture time had little effect on the soil Pi-bic levels, suggesting that the system maintains an equilibrium between the $\mathrm{P}$ available to the solution and the labile $\mathrm{P}$ fraction.

The Po-bic levels increased in the 0.0-0.05 $\mathrm{m}$ layer 20 years after TR implementation in comparison with the levels observed 3 years after TR implementation, and the CE area had Po-bic levels similar to those in the TR20 area (Table 3). The higher Po-bic levels in the TR20 area when compared to the TR3 area, are a consequence of the soil handling, which favored an increase in the SOM contents, enabling a higher. $\mathrm{P}$ uptake in the organic portion. This pattern can be best evidenced by the higher carbon content, LOM and humic acid fractions quantified in TR20 when compared to the area of TR3 (Table 2).

Similar Po-bic levels in the CE and the TR20 areas can be attributed to the fact that this $\mathrm{P}$ fraction represents an important source of labile $\mathrm{P}$ to the plants in areas that do not receive fertilization, being proportionally higher than the Pi-bic levels, as observed in the PA and CE areas. Therefore, in more stable systems such as the $\mathrm{CE}$, where there is usually a constant delivery of litterfall, and the SOM mineralization occurs more slowly, there is a tendency for Po-bic accumulation (BEUTLER, 2012). It is also possible that the higher Po-bic levels in the TR2 0 and CE areas are associated with the constant delivery of litterfall to the soil, resulting in higher SOM amounts and fulvic acid fractions (Table 2), and consequently higher $\mathrm{P}$ supplies through the mineralization of these SOM fractions.

In the 0.05-0.10 m layer, the Po-bic levels were similar between the TR areas, and the TR20 area was the only one that harbored values higher than those observed for the CE area (Table 3). These results demonstrate that in TR areas, the higher variations in the labile Po levels occur in the most superficial layer, because of the addition of organic residues. The higher values of labile Po in the TR20 in comparison with the $\mathrm{CE}$ area may be associated with the decomposition of different radicular systems of a variety of cultures adopted over time since the system was implemented. A similar pattern was observed by Olibone and Rosolem (2010) when they evaluated the $\mathrm{P}$ fractions after the addition of phosphates to soybean cultures in a TR area 5 years after implementation. These authors also observed an increase in the levels of Po after soybean harvest, attributing this result to the decomposition of radicular systems.

Another important observation related to this labile $\mathrm{P}$ fraction is that, in the oldest TR areas (15 and 20 years after implementation), the ratios $\mathrm{Po} /$ Pt are more uniformly distributed (TR2 $0_{0.00-0.05} \mathrm{~m}$ - 49\%; TR20 $0.05-0.10 \mathrm{~m}-36 \%$; TR $15_{0,00-0.05 \mathrm{~m}}-52 \%$;

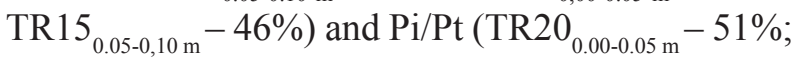
TR20 $0.05-0.10 \mathrm{~m}-64 \%$; TR15 $5_{0.00-0.05 \mathrm{~m}}-48 \%$; TR15 $0.10 \mathrm{~m}-54 \%$ ), while in the areas where the TR was more recently implemented (TR3) or those that 
never received fertilization there is a predominance of Po over Pi. These results suggest that the higher SOM amounts in the oldest TR areas contribute to a lower MPAC and to the increase in the P liability, favoring a more uniform distribution between its organic and inorganic forms. Such a distribution may have been caused by a reduction in the number of $\mathrm{P}$ adsorption sites and/or by the formation of complexes between $\mathrm{P}$ and low molecular weight acids and their consequent mineralization.

The CE and PA areas presented lower levels of $\mathrm{Pt}-\mathrm{H}$ and $\mathrm{Pi}-\mathrm{H}$ (0.00-0.10 $\mathrm{m})$ in comparison with the TR areas (Table 4). These results may have been caused by the lack of phosphorus-based fertilization in these areas, where the moderately labile P may supply the $\mathrm{P}$ needs of the culture. According to Novais et al. (2007), in highly weathered soils and/ or in soils without fertilization, the Po availability is highly dependent on the moderately labile inorganic and organic fractions. Upon evaluation of the $P$ fractions in a Cerrado Latosol in areas of CE, PA, and TR with integrated crop-livestock (ILP), Beutler (2012), also observed lower Pt-H and Pi-H levels in non-fertilized areas. Similarly, Rodrigues (2013) found higher levels of moderately labile Pi in TR areas as compared to a native Cerrado area with Red Latosol.

Table 4. Levels of total phosphorus (Pt), inorganic phosphorus (Pi), and organic phosphorus (Po), extractable in acid solution $(\mathrm{H})$, in the different soil layers and soil exploration systems, in Montividiu- GO.

\begin{tabular}{|c|c|c|c|c|c|c|}
\hline \multirow{3}{*}{ Depth (m) } & \multicolumn{6}{|c|}{ Systems evaluated $^{1}$} \\
\hline & $\mathrm{CE}$ & $\mathrm{PA}$ & TR3 & TR15 & TR20 & $\mathrm{CV}(\%)$ \\
\hline & \multicolumn{6}{|c|}{ Pt-H $\left(\mathrm{mg} \mathrm{kg}^{-1}\right)$} \\
\hline $0.0-0.05$ & $2.38 \mathrm{~d}^{*}$ & $1.99 \mathrm{e}$ & $3.13 \mathrm{c}$ & $3.56 \mathrm{~b}$ & $5.43 \mathrm{a}$ & 8.88 \\
\hline \multirow[t]{2}{*}{$0.05-0.10$} & $2.25 \mathrm{~d}$ & $1.43 \mathrm{e}$ & $3.24 \mathrm{c}$ & $4.51 \mathrm{~b}$ & $7.72 \mathrm{a}$ & 11.49 \\
\hline & \multicolumn{6}{|c|}{$\mathrm{Pi}-\mathrm{H}\left(\mathrm{mg} \mathrm{kg}^{-1}\right)$} \\
\hline $0.0-0.05$ & $1.47 \mathrm{c}$ & $1.90 \mathrm{c}$ & $2.89 \mathrm{~b}$ & $3.03 \mathrm{~b}$ & $4.88 \mathrm{a}$ & 5.76 \\
\hline \multirow[t]{2}{*}{$0.05-0.10$} & $1.24 \mathrm{c}$ & $0.97 \mathrm{c}$ & $2.51 \mathrm{~b}$ & $2.85 \mathrm{~b}$ & $6.21 \mathrm{a}$ & 11.43 \\
\hline & \multicolumn{6}{|c|}{ Po-H (mg kg-1) } \\
\hline $0.0-0.05$ & $0.91 \mathrm{a}$ & $0.09 \mathrm{~d}$ & $0.24 \mathrm{c}$ & $0.53 \mathrm{~b}$ & $0.55 \mathrm{~b}$ & 24.36 \\
\hline $0.05-0.10$ & $1.01 \mathrm{a}$ & $0.46 \mathrm{c}$ & $0.73 \mathrm{~b}$ & $1.66 \mathrm{a}$ & $1.50 \mathrm{a}$ & 23.99 \\
\hline
\end{tabular}

*Averages followed by the same lower case letter in a given line indicate solo exploration systems that do not significantly differ according to the t-test at the 5\% significance level. ${ }^{1} \mathrm{CE}$ - native cerrado; PA - Pasture; TR3 - tillage system with three years of implementation; TR15 - tillage system with 15 years of implementation; TR20 - tillage system with 20 years of deployment.

We also observed that there was an increase in the Pt-H levels (0.00-0.10 $\mathrm{m})$ as a function of time since TR implementation, as well is in the Pi-H levels in the TR areas with 20 years of implementation when compared with TR areas 3 years after implementation (Table 4). According to Souza (2008), such an increase may be a consequence of the annual addition of phosphorus-based fertilizers, which initially promotes an increase in the levels of labile inorganic P. Along the years, this $\mathrm{P}$ is adsorbed, through inner-sphere complexation, to iron and aluminum oxides, increasing the levels of moderately labile P. One must take into account that the moderately labile fraction can serve as both a source and a drain of available P, depending on the amount of $\mathrm{P}$ added via fertilization.

Therefore, we can consider that, in function of the time since TR implantation, the addition of phosphorus-based fertilizers may cause saturation of the adsorption sites of labile $\mathrm{P}$ and the accumulation of Pi in the moderately labile fraction when the system maintenance phase is achieved. Rotta (2012) obtained similar results upon evaluation of TR areas 7, 11, and 16 years after implementation in the Cerrado region. According to this author, the accumulation of $\mathrm{Pi}$ in the labile and 
moderately labile fractions along the years since TR implementation may help to reduce the need for addition of phosphorus-based fertilizers, since the soil will gradually trigger a natural depletion process, culminating with a reduced use of fertilizers and a more efficient phosphorus-based fertilization.

Similar to what was observed for the Po-bic levels, the PA area presented lower Po-H and Po-H levels $(0.0-0.10 \mathrm{~m})$ when compared to the other areas (Table 4). We again point out that this result is a consequence of the degradation state caused by the lack of appropriate handling as well as by the low SOM amounts.

We observed that the oldest TR areas presented Po-H levels $(0.0-0.10 \mathrm{~m})$ similar among each other and higher than the TR area three years after implementation (Table 4). This result can also be attributed to the time since the system was implemented; the oldest TR areas, because of the long period of deposition of plant residues of different qualities, present more recalcitrant organic matter, such as humic acid (Table 2), which is more resistant to degradation by soil microorganisms, thus leading to a higher accumulation of that $\mathrm{P}$ fraction. Gonçalves and Meurer (2009) mention that the moderately labile Po is the P fraction associated with humic acids.

Higher Po-H levels are found in the 0.0-0.05 $\mathrm{m}$ layer in the $\mathrm{CE}$ area as compared to the other areas, and similar levels of the same $\mathrm{P}$ fraction in comparison with the TR15 and TR20 areas in the 0.05-0.10 m layer (Table 4). This observation demonstrates that in the $\mathrm{CE}$ areas, a large portion of soil $\mathrm{P}$ is found in the moderately labile fraction, acting as $\mathrm{P}$ reservoir, since this fraction may serve as both a source and a drain of P. The Po-H levels in the CE area may also be associated with the high contents of the humic acid observed in this area (Table 2). Similar observations were recorded by Beutler (2012), who also found higher Po-H levels in the CE area as compared to a TR area.

The third extraction was performed with a sodium hydroxide $(\mathrm{NaOH})$ solution $\left(0.5 \mathrm{~mol} \mathrm{~L}^{-1}\right)$. The $\mathrm{P}$ fractions extractable in alkaline solution $(\mathrm{OH})$ are regarded by Bowman e Cole (1978) as moderately resistant (Table 5). Once more, the CE and PA areas presented the lowest $\mathrm{Pt}-\mathrm{OH}$ and $\mathrm{Pi}-\mathrm{OH}$ levels when compared to the TR areas (Table 5). These results can be explained by the lack of fertilization is these areas, that is, as there is no constant maintenance of the Pi levels through fertilization, the Pi tends to be adsorbed mostly by moderately labile sites (Table 4) and/or by the more recalcitrant organic fractions, whereas the moderately resistant fraction has a tendency to present avid Pi adsorption sites that are not occupied. Beutler (2012) also observed lower Pt-OH and Pi-OH levels in CE and PA areas in comparison to TR areas. The author attributes this observation to a long period of addition of phosphorus-based fertilizers, which in turn favors the temporary stabilization of the electrical charges on the surface of the iron and aluminum oxides.

The TR3 and TR15 areas presented Pt-OH and Pi-OH levels that were similar between each other but lower than those in the TR20 area (Table 5). Such pattern is a consequence of the fact that this is the oldest TR area, which received phosphorusbase fertilizers for a longer time, incrementing the specific adsorption of $\mathrm{Pi}$ to the $\mathrm{Fe}$ and $\mathrm{Al}$ oxides. However, it observed that in the TR20 area the proportion of $\mathrm{Po}-\mathrm{OH}$ in the $\mathrm{Pt}-\mathrm{OH}$ is higher than that of Pi-OH. This suggests that the increase in the SOM amounts in a function of time since TR implementation may cause the incorporation of $\mathrm{P}$ to the more recalcitrant organic fraction, reducing its direct adsorption to the soil minerals. In contrast to our observations, Rotta (2012), when evaluating a Plinthosol, did not observe any differences in the slightly labile P between TR areas 7, 11, and, 16 years after implementation, suggesting that this fraction is not affected by the annual addition of fertilizers, and that these areas have reached their maximum capacity of $\mathrm{P}$ adsorption in this more recalcitrant fraction. However, Souza (2008), when evaluating the $\mathrm{P}$ fractions in a Red Latosol in a TR area with ILP, verified an increase in the slightly labile $\mathrm{P}$ during the six years since TR implementation. 
Table 5. Levels of total phosphorus (Pt), inorganic phosphorus (Pi), and organic phosphorus (Po), extractable in alkaline solution $(\mathrm{OH})$, in the different soil layers and soil exploration systems, in Montividiu- GO, Brazil.

\begin{tabular}{|c|c|c|c|c|c|c|}
\hline \multirow{3}{*}{ Depth (m) } & \multicolumn{6}{|c|}{ Systems evaluated $^{1}$} \\
\hline & $\mathrm{CE}$ & $\mathrm{PA}$ & SPD3 & SPD15 & SPD20 & $\mathrm{CV}(\%)$ \\
\hline & \multicolumn{6}{|c|}{ Pt-OH $\left(\mathrm{mg} \mathrm{kg}^{-1}\right)$} \\
\hline $0.0-0.05$ & $1.73 \mathrm{c}^{*}$ & $1.32 \mathrm{c}$ & $2.38 \mathrm{~b}$ & $2.69 \mathrm{~b}$ & $3.76 \mathrm{a}$ & 15.46 \\
\hline \multirow[t]{2}{*}{$0.05-0.10$} & $1.20 \mathrm{c}$ & $1.21 \mathrm{c}$ & $2.52 \mathrm{~b}$ & $2.36 \mathrm{~b}$ & $3.39 \mathrm{a}$ & 6.67 \\
\hline & \multicolumn{6}{|c|}{$\mathrm{Pi}-\mathrm{OH}\left(\mathrm{mg} \mathrm{kg}^{-1}\right)$} \\
\hline $0.0-0.05$ & $0.67 \mathrm{c}$ & $0.56 \mathrm{c}$ & $1.40 \mathrm{~b}$ & $1.27 \mathrm{~b}$ & $1.50 \mathrm{a}$ & 8.75 \\
\hline \multirow[t]{2}{*}{$0.05-0.10$} & $0.58 \mathrm{c}$ & $0.56 \mathrm{c}$ & $1.45 \mathrm{~b}$ & $1.40 \mathrm{~b}$ & $1.76 \mathrm{a}$ & 10.09 \\
\hline & \multicolumn{6}{|c|}{ Po-OH $\left(\mathrm{mg} \mathrm{kg}^{-1}\right)$} \\
\hline $0.0-0.05$ & $1.05 \mathrm{~b}$ & $0.75 \mathrm{c}$ & $0.97 \mathrm{~b}$ & $1.41 \mathrm{~b}$ & $2.26 \mathrm{a}$ & 27.15 \\
\hline $0.05-0.10$ & $0.62 \mathrm{c}$ & $0.66 \mathrm{c}$ & $1.06 \mathrm{~b}$ & $0.95 \mathrm{~b}$ & $1.64 \mathrm{a}$ & 11.47 \\
\hline
\end{tabular}

*Averages followed by the same lower case letter in a given line indicate solo exploration systems that do not significantly differ according to the t-test at the 5\% significance level. ${ }^{1} \mathrm{CE}$ - native cerrado; PA - Pasture; TR3 - tillage system with three years of implementation; TR15 - tillage system with 15 years of implementation; TR20 - tillage system with 20 years of deployment.

For the Po-OH levels, the TR3 and TR15 presented values similar among each other but lower than those found for TR20 $(0,00-0,10 \mathrm{~m})$, while the $\mathrm{CE}$ area also presented levels similar to the TR3 and TR15 areas in the 0,00-0,05 m layer (Table 5). The highest Po-OH contents in the TR20 compared with the remaining areas is a consequence of the highest amount and diversity of residues delivered to the soil, what may contribute to an increased release of high molecular organic acids, which can adsorb $\mathrm{P}$ in recalcitrant structures. Similar results were obtained by Tokura et al. (2002), who, when evaluating TR and Cerrado areas with Red Latosol, observed higher Po-OH levels in cultivated than in non-cultivated areas, a pattern that was observed in the $0,05-0,10 \mathrm{~m}$ layer.

The majority of the total soil phosphorus in the TR areas is found in the moderately labile (TR3 $55 \%$; TR $15-55 \%$; TR20 - 56\% in the $0.0-0.05 \mathrm{~m}$ layer and TR3 - 54\%; TR $15-62 \%$; TR20 - 66\% in the $0.05-0.10 \mathrm{~m}$ layer), and inorganic forms (TR3 $51 \%$; TR $15-47 \%$; TR20 - 50\% in the $0.0-0.05 \mathrm{~m}$ layer, and TR $3-42 \%$; TR $15-39 \%$; TR20 - 53 \% in the $0.05-0.10 \mathrm{~m}$ layer). According to Souza (2008), this is due to the annual addition of phosphorusbased fertilizers, with the $\mathrm{P}$ initially preferentially labile inorganic fraction and, with time, this $\mathrm{P}$ is adsorbed via intern-sphere complexation to the iron and aluminum oxides, incrementing the moderately labile inorganic fraction. Similar observations were made by Beutler (2012). Evaluating an ILP with Red Latosol in Montividiu-GO, Brazil, they also found predominantly the moderately labile (70\% of $\mathrm{Pt}$ ) and inorganic (95\%) P fractions.

Through principal component analysis (PCA), we observed the correlation between the $\mathrm{P}$ fractions and other variables (Figures 1 and 2). The evaluated variables were heterogeneously distributed throughout the areas. With such a distribution, it is possible to verify that the PA is isolated from the other areas in the F1 direction, followed by the TR chronosequences and the CE area between the TR3 and TR15 (Figures 1 and 2). This detachment of the PA area from the negative region of the F1 axis can be attributed to its degradation state, with lower values of Pi-bic, Po-bic, Pt-H, Po-H, and $\mathrm{Po}-\mathrm{OH}$ in comparison with the remaining areas. This pattern can be justified by the higher MPAC of the PA area (GUARESCHI et al., 2015), as well as the lower contents of the humic, Com (GUARESCHI et al., 2013), SOM, and C (GUARESCHI et al., 2012). 
Figure 1. Ordination diagrams designed using principal component analysis of the characteristics evaluated in soil samples collected in the 0.0-0.05 m layer.

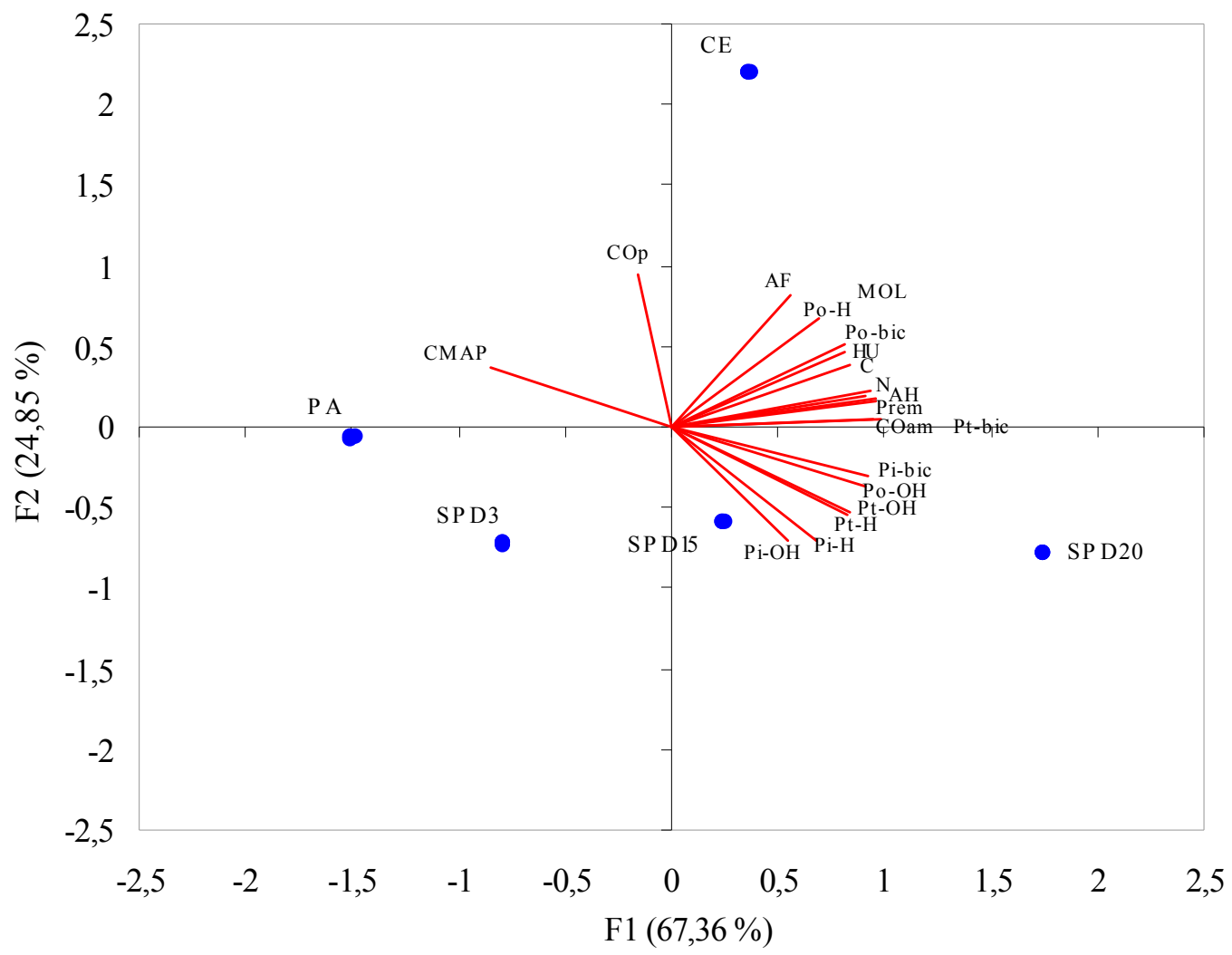

The proximity between the positive autovectors (Pi-bic, Pi-H, Pi-OH, Pt-H, and Pt-OH) of the TR20 in the direction of the chronosequence along the F1 axis (Figures 1 and 2) reflects the high levels of those fractions in this area, and can be attributed to a long time during which samples were collected at the time of phosphorus-based fertilization. Another point to be highlighted, and that contributed to this distribution are the lowest values of MPAC (GUARESCHI et al., 2015) that may be due to the higher content of C, LOM, HA, and FA quantified in this area (GUARESCHI et al., 2012, 2013). This explanation also applies for the grouping observed for the $\mathrm{Po}-\mathrm{OH}$ (Figure 1), Po-bic, and $\mathrm{Po}-\mathrm{OH}$ (Figure 2) autovectors of the TR20 area, which may also be associated with the higher levels of C, LOM, and FA observed in this area whewe o the the others. The higher organic matter contents (GUARESCHI et al., 2012) may provide Po-bic through its mineralizations. In addition, in this area, the higher levels of HA, which represents an organic fraction more difficult to be mineralized and with higher complexation capacity, may contribute to the increase in the Po-OH levels.

Through PCA, we observed that the groupings of the Po-bic, Po-H (Figure 1), and Po-H (Figure 2) autovectors are accompanied by the COp, FA, LMO, C, and HA autovectors, near the CE area. This pattern demonstrates that the P-bic levels are similar to those found in the TR20 areas and are higher than those of the other areas. This can be a consequence of organic matter mineralization, because the highest COp, C, and FA levels were observed in this area (GUARESCHI et al., 2012, 2013). The higher Po-H levels may be associated with higher HA content (GUARESCHI et al., 2013). 
Figure 2. Ordination diagrams designed using principal component analysis of the characteristics evaluated in soil samples collected in the $0.05-0.10 \mathrm{~m}$ layer.

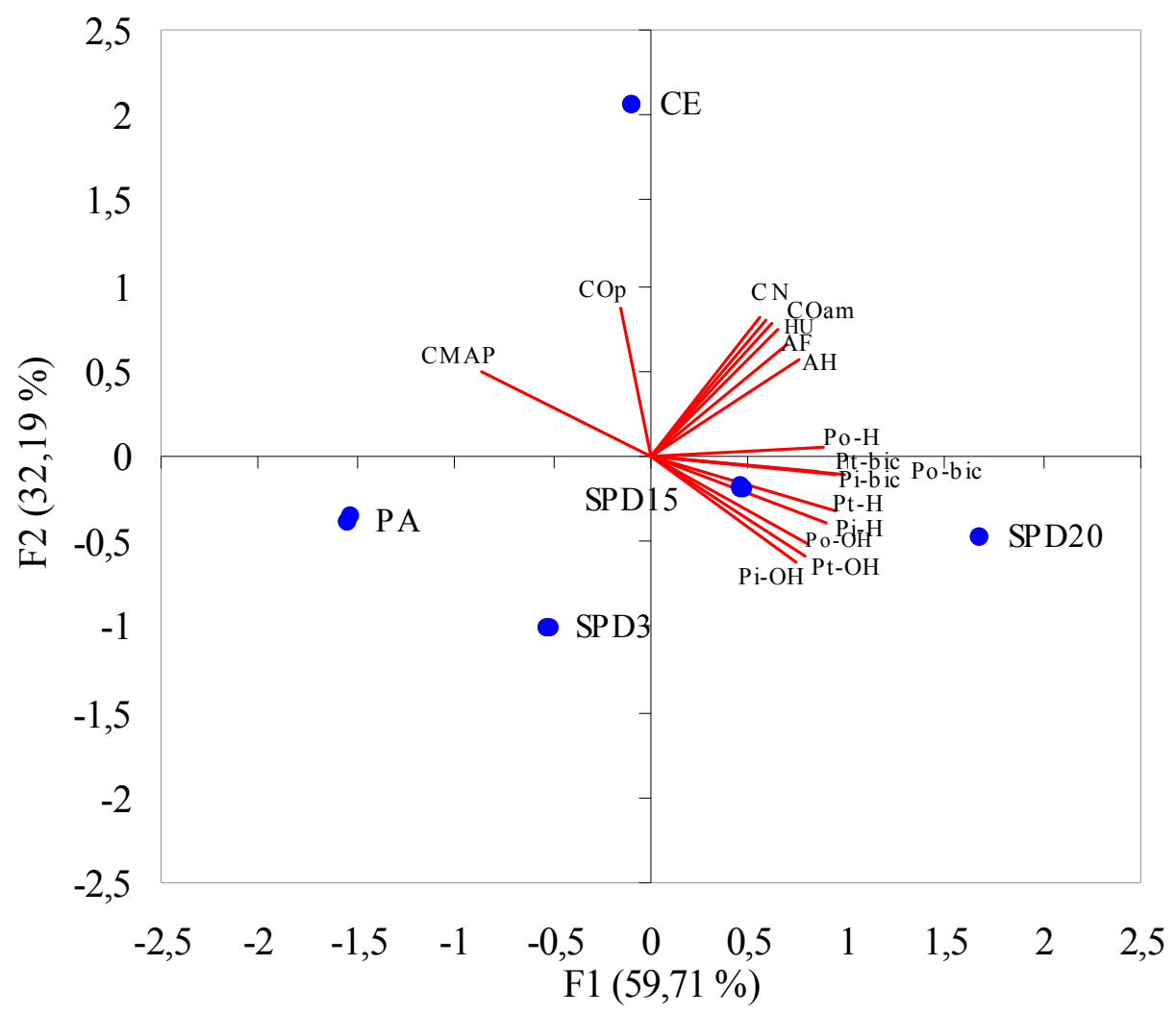

\section{Conclusions}

The constantuse of phosphorus-based fertilization and the increment of MOS contents increase the levels of labile, moderately labile, and moderately resistant organic and inorganic $\mathrm{P}$, in a function of the time since TR implementation. There is a tendency of total $\mathrm{P}$ accumulation mostly in its moderately labile inorganic form. Unexpectedly high labile and moderately labile organic $\mathrm{P}$ values were observed in the native Cerrado area, demonstrating that these are the predominant fractions of $\mathrm{P}$ in the soil.

The lack of appropriate handling in the pasture areas resulted in lower levels of labile organic and inorganic $\mathrm{P}$, and moderately labile as well as moderately resistant organic $\mathrm{P}$, in comparison with the other evaluated areas. Therefore, it is evident that the lack of appropriate handling of the pasture leads to soil degradation, and requires a lot of attention, since a large part of the Brazilian Cerrado is occupied by Urochloa sp. pastures, which are probably in a similar state of degradation.

Using principal component analysis, correlations between the evaluated soil attributes was observed, enabling the association of the $\mathrm{P}$ levels in the analyzed fractions with the variables MPAC, HA, FA, LOM, COp, and COm.

\section{References}

ALMEIDA, J. A.; TORRENT, J.; BARRÓN, V. Cor de solo, formas do fósforo e adsorção de fosfatos em Latossolos desenvolvidos de basalto do Extremo-Sul do Brasil. Revista Brasileira de Ciência do Solo, Viçosa, MG, v. 27, n. 6, p. 985-1002, 2003.

ANDRADE, R. G.; LEIVAS, J. F.; GARÇON, E. A. M.; SILVA, G. B. S.; GOMES, D.; VICENTE, L. E.; BOLFE, E. L.; VICTORIA, D. C. Indicativo de degradação de pastagens a partir de dados Spot Vegetation. In: 
SIMPÓSIO BRASILEIRO DE SENSORIAMENTO REMOTO, 16., 2013, Foz do Iguaçu. Anais... Foz do Iguaçu: INPE, 2013. p. 6917-6922.

BEUTLER, S. J. Matéria orgânica do solo e fósforo orgânico em área de integração lavoura-pecuária no cerrado goiano. 2012. Dissertação (Mestrado em Agronomia) - Universidade Federal Rural do Rio de Janeiro, Seropédica.

BOWMAN, R. A. A sequential extraction procedure with concentrated sulfuric acid and dilute base for soil organic phosphorus. Soil Science Society of America Journal, Madison, v. 53, n. 2, p. 362 366, 1989.

BOWMAN, R. A.; COLE, C. V. An exploratory method for fractionation of organic phosphorus from grassland soils. Soil Science, Baltimore, v. 125, n. 2, p. 95-101, 1978.

BRAVO, C. A.; GIRALDEZ, J. V.; ORDOÑEZ, R.; GONZALEZ, P.; TORRES, F. P. Long term influence of conservation tillage on chemical properties of surface horizon and legume crops yield in a Vertisol of Southern Spain. Soil Science, Baltimore, v. 172, n. 2, p. 141-148, 2007.

BUSTAMANTE, M. M. C.; NARDOTO, G. B.; PINTO, A. S.; REZENDE, J. C. F.; TAKAHASHI, F. S. C.; VIEIRA, L. C. G. Potential impacts of climate change on biogeochemical functioning of Cerrado ecosystems. Brazilian Journal of Biology, São Carlos, v. 72, n. 3, p. 655-671, 2012.

CARNEIRO, L. F.; RESENDE, A. V.; FURTINI NETO, A. E.; SANTOS, J. Z. L.; CURI, N.; REIS, T. H. P.; VALLE, L. A. R. Frações de fósforo no solo em resposta à adubação fosfatada em um Latossolo com diferentes históricos de uso. Revista Brasileira de Ciência do Solo, Viçosa, MG, v. 35, n. 2, p. 483-491, 2011.

COSTA JUNIOR, C. Estoque de carbono e nitrogênio e agregação do solo sob diferentes sistemas de manejo agrícola no Cerrado, em Rio Verde (GO). 2008. Dissertação (Mestrado em Química na Agricultura e no Ambiente) - Centro de Energia Nuclear na Agricultura, Universidade de São Paulo. Piracicaba.

DUDA, G. P. Conteúdo de fósforo microbiano, orgânico e biodisponivel em diferentes classes de solo. 2000. Tese (Doutorado em Agronomia) - Universidade Federal Rural do Rio de Janeiro, Seropédica.

EBERHARDT, D. N.; VENDRAME,P.R. S.;BECQUER, T.; GUIMARÃES, M. F. Influência da granulometria e da mineralogia sobre a retenção do fósforo em Latossolos sob pastagens no cerrado. Revista Brasileira de Ciência do Solo, Viçosa, MG, v. 32, n. 3, p. 1009-1016, 2008.

\section{EMPRESA BRASILEIRA DE PESQUISA} AGROPECUÁRIA - EMBRAPA. Manual de métodos de análise de solo. 2. ed. Rio de Janeiro: Embrapa Solos, 1997. $212 \mathrm{p}$.

. Sistema brasileiro de classificação de solos. 3. ed. Rio de Janeiro: Embrapa Solos, 2013. 353 p.

FONTANA, A.; PEREIRA, M. G.; LOSS, A.; CUNHA, T. J. F.; SALTON, J. C. Fósforo remanescente e correlação com as frações da matéria orgânica em um Latossolo Vermelho distroférrico sob diferentes sucessões de cultura em plantio direto. Revista Brasileira de Agrociências, Pelotas, v. 14, n. 1, p. 1-6, 2008.

GALVANI, R.; HOTTA, L. F. K.; ROSOLEM, C. A. Phosphorus sources and fractions in an Oxisol under notilled soybean. Scientia Agricola, Piracicaba, v. 65, n. 4, p. 415-421, 2008.

GATIBONI, L. C.; KAMINSKI, J.; RHEINHEIMER, D. S.; KAMINSKI, J.; FLORES, J. P. C. Biodisponibilidade de formas de fósforo acumuladas em solo sob sistema plantio direto. Revista Brasileira de Ciência do Solo, Viçosa, MG, v. 31, n. 4, p. 691-699, 2007.

GONÇALVES, G. K.; MEURER, E. J. Frações de fósforo no solo e sua relação com a absorção pelas plantas de arroz irrigado por alagamento em solos do rio grande do sul. Revista Brasileira de Ciência do Solo, Viçosa, MG, v. 33, n. 2, p. 357-362, 2009.

GUARESCHI, R. F. Matéria orgânica e atributos químicos e físicos do solo em uma cronossequência de agricultura sob plantio direto no cerrado Goiano. 2013. Tese (Doutorado em Agronomia) - Universidade Federal Rural do Rio de Janeiro, Seropédica.

GUARESCHI, R. F.; PEREIRA, M. G.; PERIN, A. Adsorption of $\mathrm{P}$ and forms of iron in no-tillage areas in the 'Cerrado'biome. Acta Scientiarum. Agronomy, Maringá, v. 37, n. 1, p. 109-116, 2015.

Deposição de resíduos vegetais, matéria orgânica leve, estoques de carbono e nitrogênio e fósforo remanescente sob diferentes sistemas de manejo no cerrado goiano. Revista Brasileira de Ciência do Solo, Viçosa, MG, v. 36, n. 3, p. 909-920, 2012.

Frações da matéria orgânica em áreas de Latossolo sob diferentes sistemas de manejo no Cerrado do estado de Goiás. Semina: Ciências Agrárias, Londrina, v. 34, n. 6, p. 2615-2628, 2013.

GUPPY, C. N.; MENZIES, N. W.; MOODY, P. W.; BLAMEY, F. P. C. Competitive sorption reactions between phosphorus and organic matter in soil: A review. Australian Journal of Soil Research, Melbourne, v. 43, n. 1, p. 189-202, 2005. 
NOVAIS, R. F.; SMYTH, T. J.; NUNES, F. N. Fósforo. In: NOVAIS, R. F.; ALVAREZ, V. V. H.; BARROS, N. F.; FONTES, R. L. F.; CANTARUTTI, R. B.; NEVES, J. C. L. (Ed.). Fertilidade do solo. Viçosa, MG: SBCS, 2007. p. 276-374.

OLIBONE, D.; ROSOLEM, C. A. Phosphate fertilization and phosphorus forms in an Oxisol under no-till. Scientia Agricola, Piracicaba, v. 67, n. 4, p. 465-471, 2010.

PARTELLI, F. L.; BUSATO, J. B.; VIEIRA, H. D.; VIANA, A. P.; CANELLAS, L. P. Qualidade da matéria orgânica e distribuição do fósforo no solo de lavouras orgânicas de café Conilon. Ciência Rural, Santa Maria, v. 39, n. 7, p. 2065-2072, 2009.

PEREIRA, M. G.; LOSS, A.; BEUTLER, S. J.; TORRES, J. L. R. Carbono, matéria orgânica leve e fósforo remanescente em áreas de Cerrado sob plantio direto, MG. Pesquisa Agropecuária Brasileira, Brasília, v. 45 , n. 5, p. 508-514, 2010.

RODRIGUES, M. Sistemas de manejo e a dinâmica das formas de fósforo e da fertilidade em solos de Cerrado. 2013. Dissertação (Mestrado em Agronomia) - Escola Superior de Agricultura Luiz de Queiroz, Piracicaba.

ROTTA, L. R. Fracionamento e disponibilidade de fósforo em uma cronossequência de cultivos sob plantio direto. 2012. Dissertação (Mestrado em Agronomia) Universidade Federal de Goiás, Jataí.

SANO, E. E.; FERREIRA, L. G.; ASNER, G. P.; STEINKE, E. T. Spatial and temporal probabilities of obtaining cloud-free Landsat images over the Brazilian tropical savanna. International Journal of Remote Sensing, New York, v. 28, n. 12, p. 2739-2752, 2007.

SANTOS, D. R.; GATIBONI, L. C.; KAMINSKI, J. Fatores que afetam a disponibilidade do fósforo e o manejo da adubação fosfatada em solos sob sistema plantio direto. Ciência Rural, Santa Maria, v. 38, n. 2, p. 576-586, 2008.

SILVA, A. A.; NÓBREGA, J. C. A.; CURI, N.; SIQUEIRA, J. O.; SÁ, J. J. G.; MARQUES, M.; MOTTA, P. E. F. Frações de fósforo em Latossolos. Pesquisa Agropecuária Brasileira, Brasília, v. 38, n. 10, p. 1197-1207, 2003.
SILVA, F. A. S.; AZEVEDO, C. A. V. Versão do programa computacional Assistat para o sistema operacional Windows. Revista Brasileira de Produtos Agroindustriais, Campina Grande, v. 4, n. 1, p. 71-78, 2002.

SILVA, F. F.; FREDDI, O. S.; CENTURION, J. F.; ARATANI, R. G.; ANDRIOLI, F. F.; ANDRIOLI, I. Propriedades físicas de um Latossolo vermelho cultivado no sistema plantio direto. Irriga, Botucatu, v. 13, n. 2, p. 191-204, 2008.

SIQUEIRA NETO, M.; SCOPEL, E.; CORBEELS, M.; CARDOSO, A. N.; DOUZET, J. M.; FELLER, C.; PICCOLO, M. C.; CERRI, C. C.; BERNOUX, M. Soil carbon stocks under no-tillage mulch-based cropping systems in the Brazilian Cerrado: An on-farm synchronic assessment. Soil and Tillage Research, Amsterdam, v. 110, n. 1, p. 187-195, 2010.

SOUZA, E. D. Evolução da matéria orgânica, do fósforo e da agregação do solo em sistema de integração agricultura-pecuária em plantio direto, submetido a intensidades de pastejo. 2008. Tese (Doutorado em Agronomia) - Universidade Federal do Rio Grande do Sul, Porto Alegre.

SOUZA, R. F.; FAQUIN, V.; SOBRINHO, R. R. L.; OLIVEIRA, E. A. B. Influência de esterco bovino e calcário sobre o efeito residual da adubação fosfatada para a Brachiaria brizantha cultivada após o feijoeiro. Revista Brasileira de Ciência do Solo, Viçosa, v. 34, n. 1, p. 143-150, 2010.

SOUZA, R. F.; FAQUIN, V.; TORRES, P. R. F.; BALIZA, D. P. Calagem e adubação orgânica: influência na adsorção de fósforo em solos. Revista Brasileira de Ciência do Solo, Viçosa, MG, v. 30, n. 6, p. 975-983, 2006.

TOKURA, A. M.; FURTINI NETO, A. E.; CURI, N.; FAQUIN, V.; KURIHARA, C. H.; ALOVISI, A. A. Formas de fósforo em solo sob plantio direto em razão da profundidade e tempo de cultivo. Pesquisa Agropecuária Brasileira, Brasília, v. 37, n. 10, p. 1467-1476, 2002.

TORMENA, C. A.; ROLOFF, G.; SÁ, J. C. M. Propriedades físicas do solo sob plantio direto influenciadas por calagem, preparo inicial e tráfego. Revista Brasileira de Ciência do Solo, Viçosa, MG, v. 22, n. 02, p. 301-309, 1998. 